\title{
Rothmund-Thomson syndrome: Immuno-osseous challenges
}

\author{
I Meyts $^{1 *}$, L De Somer ${ }^{1}$, X Bossuyt ${ }^{2}$, M-A Morren ${ }^{3}$, K Devriendt $^{4}$, C Wouters $^{1}$ \\ From 18th Pediatric Rheumatology European Society (PReS) Congress \\ Bruges, Belgium. 14-18 September 2011
}

\section{Background}

Rothmund-Thomson (RTS) syndrome is a rare autosomal recessively inherited genodermatosis.. It is characterized by poikiloderma, small stature, skeletal and dental abnormalities, cataract, and an increased risk of cancer. The syndrome is caused by mutations in RECQL4 at 8q24.

\section{Aims}

To describe the osseous and immunologic features of three patients with genetically confirmed RTS.

\section{Methods}

Immunological investigation, $\mathrm{x}$-ray imaging and bone densitometry were performed at time of the first visit to the combined rheumatology-immunology clinic.

\section{Results}

All patients had characteristic poikiloderma as well as thumb anomalies. They were born dysmaturely and presented with failure to thrive.

Age at genetic diagnosis was 5y, 4y and 3y for P1, P2, P3.

Osteopenia and abnormal metaphyseal trabeculation of bones were striking on the initial skeletal survey in all patients. Z-scores on DXA scan were $-0.1,-1.1$ and -1.2 for P1, P2, P3 respectively at presentation. The presentation in P2 was dramatic with 6 fractures in upper and lower extremities and subluxation of both radii.

All patients were suffering from recurrent chest infections. P1 had granulomatous skin inflammation following primo VZV infection. All patients have low switched memory B cells for age, P1 has IgG2 deficiency. P1 and P3 have IgM deficiency. P1 and P3 have specific polysaccharide antibody deficiency. Results are pending for P2.

\footnotetext{
* Correspondence: Isabelle.Meyts@uzleuven.be

${ }^{1}$ Department of Pediatric Immunology, University Hospitals Leuven, Belgium Full list of author information is available at the end of the article
}

All receive prophylactic antibiotics. P1 is treated with subcutaneous immunoglobulin substitution.

\section{Conclusion}

RTS is a genodermatosis with variable clinical presentation and course. Our observation of severe bone abnormalities and associated immunodeficiency merits attention for optimal management of these patients.

\section{Author details}

'Department of Pediatric Immunology, University Hospitals Leuven, Belgium. ${ }^{2}$ Laboratory Medicine, University Hospitals Leuven, Belgium. ${ }^{3}$ Department of Dermatology, University Hospitals Leuven, Belgium. ${ }^{4}$ Center for Medical Genetics, University Hospitals Leuven, Belgium.

Published: 14 September 2011

\section{doi:10.1186/1546-0096-9-S1-P312}

Cite this article as: Meyts et al:: Rothmund-Thomson syndrome:

Immuno-osseous challenges. Pediatric Rheumatology 2011 9(Suppl 1):P312.
Submit your next manuscript to BioMed Central and take full advantage of:

- Convenient online submission

- Thorough peer review

- No space constraints or color figure charges

- Immediate publication on acceptance

- Inclusion in PubMed, CAS, Scopus and Google Scholar

- Research which is freely available for redistribution

Submit your manuscript at www.biomedcentral.com/submit

\section{() Biomed Central}

